\title{
Hegemonic masculinity and femininity in the 'backblocks' of the Waikato and King Country 1860s-1930s
}

\author{
MEG PARSONS AND KAREN FISHER \\ School of Environment, University of Auckland
}

\section{Abstract}

Through the medium of archival and visual sources, as well as oral histories, this study explores the transformation of one freshwater place, the Waipa River located within the Waikato and King Country districts of the North Island of Aotearoa New Zealand, from the 1860s through till the 1930s. This article addresses the neglect of gender within existing environmental history and historical geography literatures on settler colonial societies, and explores the gendered dimensions of Pākehā settlers' transformation of the landscapes and waterscapes of the Wāipa River catchment. We draw attention to the role of Pākehā women in efforts to remove and remodel the indigenous forests and wetlands, and in doing so challenge the long-standing historical narrative that positioned Pākehā settler men as the sole actors in the radical environmental changes that took place within Aotearoa since the commencement of formal British colonisation in 1840. Through the lens of hegemonic masculinity and femininity we demonstrate how Pākehā gender norms informed the ways in which Pākehā men and women in the Waikato and King Country perceived their local environments (such as wetlands), their own and others' day-to-day activities, and how they interacted with other communities (both human and ecological).

Keywords: gender, environmental history, historical geography, colonialism, masculinity

\section{Introduction}

This article addresses the neglect of gender within scholarship examining the environmental history and historical geography of settler colonial societies and explores the gendered dimensions of Pākehā settlers' transformation of the landscapes and waterscapes of Aotearoa's Waikato and King Country (Te Rohe Potāe) districts from the 1860s to the 1930s. We draw attention to the role of Pākehā women in efforts to remove and remodel the forests and wetlands. 
Traditionally, environmental historians adopted, with limited consideration to gender, the simplistic storyline of Pākehā men battling against and ultimately taming the 'howling wilderness' to create productive landscapes that sought to replicate and improve on British agrarian traditions. ${ }^{1}$ More recent histories partially disrupt this narrative by examining how Māori iwi (tribe) and hapū (sub-tribe) relationships within their rohe (traditional lands and waters) were negatively impacted by dispossession and ecological colonialism. ${ }^{2}$ However, the experiences of women, and the ways in which gender norms (of masculinities and femininities) shaped resource usage remains largely overlooked within current scholarship about colonialism and environmental changes in Aotearoa New Zealand. The purpose of this article is to offer methodological and theoretical insights into researching gender within the fields of environmental history and historical geography through the use of a feminist historical geography research approach and the theoretical lens of hegemonic masculinity and masculinities.

By employing these theoretical and methodological techniques we trace how Pākehā gender hegemony (underpinned by patriarchal ideology) sought to exclude and marginalise Pākehā women within discourses of farming and landscape changes (as well as Māori and other non-white women), and to define the relationships between the farmer and the land as one that was implicitly masculine (and Pākehā). We focus on Pākehā rather than Māori gender norms, and linkages to environmental changes that occurred within the Waikato and King Country, as there is insufficient space here to attend to the gendered effects of colonisation on Māori women and men, and the impacts of settler colonialism on Māori relationships with their rohe, tūpuna (ancestors) and hauora (well-being). Indeed, as two Māori wahine (women) who are personally and professionally steeped within the Indigenous research paradigm and Indigenous methodologies, we are critically aware of the need for scholars, decisionmakers and members of the diverse publics that comprise contemporary Aotearoa to recognise the past and present realities of settler colonialism. ${ }^{3}$ However, we could not (in our opinion) provide adequate time and words to explain how Māori world views (Te Ao Māori) differed from those of Pākehā (Te Ao Pākehā), the specific gender norms that are woven through mātauraunga Māori (Māori knowledge) and tikanga (laws), and the gendered implications of colonisation, alongside discussion

\footnotetext{
1 Peter Holland, Home in the Howling Wilderness: Settlers and the Environment in Southern New Zealand (Auckland: Auckland University Press, 2013).

2 Meg Parsons and Johanna Nalau, 'Historical Analogies as Tools in Understanding Transformation', Global Environmental Change 38 (2016): 82-96, doi.org/10.1016/j.gloenvcha.2016.01.010; Alfred W. Crosby, Germs, Seeds and Animals: Studies in Ecological History: Studies in Ecological History (London: Routledge, 2015).

3 This paper forms part of a larger transdisciplinary project that seeks to explore the effects of colonisation on Māori relationships with the Waipā River and its tributaries.
} 
of Pākehā women and environmental changes. ${ }^{4}$ For further information about how Māori women's land rights and abilities to exercise their mana (authority and power) were constrained by the imposition of mid-Victorian British cultural norms and legal traditions, see the works of historians such as Tony Ballantyne and Ani Mikaere. $^{5}$

A note on the language used in this article: we deliberately chose to employ the term Pākehā to refer to people of European origin or descent instead of the more commonly used 'New Zealand Europeans'. Pākehā, as the historian Simon Dench writes, 'frames non-Maori New Zealanders from a Māori perspective'. ${ }^{6}$ Whilst at times the label 'European' may seem more appropriate, Pākehā reminds the reader of the important distinction between Māori and the European settlers. The term 'settler' is likewise criticised by scholars and indigenous community members for erasing the violence of colonisation. ${ }^{7}$ It is more accurate, many New Zealand historians argue, to use the categories of invader, coloniser and occupier. ${ }^{8}$ While the term 'settler' does imply the notion of peaceful 'settling', it also details specific forms of violence (legal, physical, epistemological and symbolic) that were inflicted on indigenous people in specific colonial relationships. ${ }^{9}$ In this article, we deliberately employ the term 'settler' in recognition of both the distinctiveness of settler colonialism from other forms of colonisation, and to highlight the whitewashing of hegemonic representations of Aotearoa's colonial history as being more humane than elsewhere. Furthermore, as two scholars whose whakapapa (genealogy) include both Māori

4 Over the last 30 years, a proliferation of scholars, building on the seminal work of Linda Tuhiwai Smith, have extended the contours of Māori research centred on a Kaupapa Māori approach across a diversity of subject areas. See Naomi Simmonds, 'Mana Wahine: Decolonising Politics', Women's Studies Journal 25, no. 2 (2011): 11-27; Clive Aspin and Jessica Hutchings, 'Reclaiming the Past to Inform the Future: Contemporary Views of Maori Sexuality', Culture, Health \& Sexuality 9, no. 4 (July 2007): 415-27, doi.org/10.1080/13691050701195119; Jessica Hutchings, 'Claiming Our Ethical Space-A Mana Wahine Conceptual Framework for Discussing Genetic Modification', He Pūkenga Körero: A Journal of Mãori Studies 8, no. 1 (2004): 17-25; Nepia Mahuika, Rethinking Oral History and Tradition: An Indigenous Perspective (Oxford: Oxford University Press, 2019).

5 Ani Mikaere, 'Maori Women: Caught in the Contradictions of a Colonised Reality', Waikato Law Review 2 (1994): 125; Tony Ballantyne, Entanglements of Empire: Missionaries, Mãori, and the Question of the Body (Auckland: Auckland University Press, 2015), doi.org/10.1515/9780822375883.

6 Simon Jeffery Dench, 'Imaging and Imagining the Waikato: A Spatial History c.1800-c.1914' (PhD diss., University of Waikato, 2018), 24.

7 Peter Gibbons, 'The Far Side of the Search for Identity-Reconsidering New Zealand History', New Zealand Journal of History 37, no. 1 (2003): 38-49; Simon Dench, 'Invading the Waikato: A Postcolonial Re-View', New Zealand Journal of History 45, no. 1 (2011): 33-49.

8 Keith Sinclair, 'Why Are Race Relations in New Zealand Better than in South Africa, South Australia or South Dakota?', New Zealand Journal of History 5, no. 2 (1971): 121-7; Raymond G. Nairn and Timothy N. McCreanor, 'Race Talk and Common Sense: Patterns in Pakeha Discourse on Maori/Pakeha Relations in New Zealand', Journal of Language and Social Psychology 10, no. 4 (1991): 245-62, doi.org/10.1177/0261927X91104002.

9 Avril Bell, Relating Indigenous and Settler Identities: Beyond Domination (Basingstoke: Palgrave Macmillan, 2014), 9, doi.org/10.1057/9781137313560. 
and Pākehā ancestors and who self-identify as 'Māori/Pākehā/other' hybrids, we consciously employ the term 'settler' to unsettle and potentially decolonise narratives about environmental history. ${ }^{10}$

We employ theorising on gender hegemony, specifically the concepts of hegemonic masculinity and femininity, to examine what was considered appropriate and desirable gendered behaviours for Pākehā women and men living in the Waikato and King Country, and the ways in which class, race and gender norms intersected to contribute to the establishment and maintenance of particular (settler colonial) landscapes. ${ }^{11}$ In doing so, we aim to contribute to scholarship on historical geography and environmental history, as well as feminist rural studies, and to add to the growth of humanities and social science scholarship that explores human-environment interactions through an intersectional lens.

\section{Methodological approach}

The primary focus of our research project was to understand how different social groups conceptualised and interacted with the Waipā River and its tributaries over two centuries, which included how specific knowledge and values shaped how Māori and Pākehā responded to environmental changes. Gender never featured in our thinking because, we now realise, we were conditioned through training and academic experiences in Indigenous environmental geography and environmental history to be attuned to indigeneity (and 'race') as a category of analysis, seminal works being largely silent on gender (or other subjectivities such as class and sexuality). ${ }^{12}$ In seeking to insert Indigenous voices into accounts of environmental geography, geographers (ourselves included) were/are guilty of myopic thinking that

10 Karen T. Fisher, 'Positionality, subjectivity, and race in transnational and transcultural geographical research', Gender, Place \& Culture 22, no.4 (2015): 1-18, doi.org/10.1080/0966369X.2013.879097.

11 R. W. Connell, 'Hegemonic Masculinity and Emphasized Femininity', Gender and Power: Society, the Person, and Sexual Politics, ed. Robert W. Connell and James W. Messerschmidt (New York: Wiley, 1987), 183-8; R. W. Connell, 'Hegemonic Masculinity: Rethinking the Concept', Gender \& Society 19, no. 6 (2005): 829-59, doi.org/ 10.1177/0891243205278639; Mark C. J. Stoddart and D. B. Tindall, 'Ecofeminism, Hegemonic Masculinity, and Environmental Movement Participation in British Columbia, Canada, 1998-2007: "Women Always Clean up the Mess”', Sociological Spectrum 31, no. 3 (April 2011): 342-68, doi.org/10.1080/02732173.2011.557065; Carrie Paechter, 'Rethinking the Possibilities for Hegemonic Femininity: Exploring a Gramscian Framework', Women's Studies International Forum 68 (May 1, 2018): 121-8, doi.org/10.1016/j.wsif.2018.03.005.

12 Brad Coombes, Jay T. Johnson and Richard Howitt, 'Indigenous Geographies I: Mere Resource Conflicts? The Complexities in Indigenous Land and Environmental Claims', Progress in Human Geography 36, no. 6 (December 2012): 810-21; Sonia Leonard et al., 'The Role of Culture and Traditional Knowledge in Climate Change Adaptation: Insights from East Kimberley, Australia', Global Environmental Change 23, no. 3 (June 2013): 623-32, doi.org/10.1016/j.gloenvcha.2013.02.012; Meg Parsons et al., 'Disrupting Path Dependency: Making Room for Indigenous Knowledge in River Management', Global Environmental Change 56 (2019): 95-113, doi.org/ 10.1016/j.gloenvcha.2019.03.008; Linda Tuhiwai Smith, Decolonizing Methodologies: Research and Indigenous Peoples (New York: Zed Books, 2013); Garth Harmsworth, Shaun Awatere and Mahuru Robb, 'Indigenous Māori Values and Perspectives to Inform Freshwater Management in Aotearoa-New Zealand', Ecology and Society 21, no. 4 (October 2016), doi.org/10.5751/ES-08804-210409. 
overlooks the intersectional subjectivities of people's lives. The shocking realisation that we were unconsciously erasing gender (despite our self-identification as feminist scholars) from the research questions we were asking and the research project we designed began when the lead author started collecting initial data (memoirs and oral histories). In the process of reading along and against the archival grain as well as listening to the stories that women (sometimes men) told about themselves, their homes, communities and environmental conditions, particular gender norms and expectations of what was socially acceptable behaviour for men and women became common themes. We, thus, returned to our research project and sought to consider how to adopt a more nuanced research approach more attuned to the complexities of lived realities. We decided to adopt a feminist historical geography approach, informed by feminist political ecology, decolonial theory and intersectionality thinking, because of the emphasis on hybrid methodological tools and the focus on analysing the multiple subjectivities and intersectional power dynamics of Waikato and King Country communities in the late nineteenth and early twentieth centuries.

Over the last three decades, a subfield of feminist historical geography has emerged, influenced by inter- and multidisciplinary feminist scholarship and the work in fields within the disciplines of geography and history, as well as post-structural, postcolonial, decolonial and postmodern theorising and approaches. ${ }^{13}$ Consequently, feminist historical geography does not conform to many of the approaches and methods employed by traditional historical geography or environmental history. For instance, the standard historical materials (court records, government reports and correspondence, journals and newspapers) often contain limited information about women's geographies and embodied experiences of places. Accordingly, feminist historical geographers draw on other primary sources that provide insight into women's lives-worlds in the past (including oral histories, drawings, clothing and other material objects, stories and travel writings). ${ }^{14}$ Following the methodological practices of feminist historical geographers and feminist environmental historians, we draw on written accounts, photographs and oral histories to piece together the highly fragmented voices of women (and some men) who lived in the Waikato and King Country (specifically within the catchment of the Waipā River) during the second half of the nineteenth and early twentieth centuries.

\footnotetext{
13 Katie Pickles, 'Locating Widows in Mid-Nineteenth Century Pictou County, Nova Scotia', Journal of Historical Geography 30, no. 1 (January 2004): 70-86, doi.org/10.1016/S0305-7488(02)00106-8; Mona Domosh and Karen M. Morin, 'Travels with Feminist Historical Geography', Gender, Place and Culture: A Journal of Feminist Geography 10, no. 3 (2003): 257-64, doi.org/10.1080/0966369032000114028.

14 Domosh and Morin, 'Travels with Feminist Historical Geography'; Jeanne Kay, 'Landscapes of Women and Men: Rethinking the Regional Historical Geography of the United States and Canada', Journal of Historical Geography 17, no. 4 (1991): 435-52, doi.org/10.1016/0305-7488(91)90026-R; Francesca Moore, 'Historical Geography, Feminist Research and the Gender Politics of the Present', Geography Compass, 2018, e12398, doi.org/10.1111/gec3.12398.
} 
The diversity of materials collected provided a necessary counterweight to colonial archives and top-down accounts of environmental history. ${ }^{15}$ Collections held in the national archives are the records of central government departments, which are legally required to prepare and deposit their documents with archives within certain time frames. ${ }^{16}$ Public library collections contain books and personal collections of individuals or families deemed important to the history and heritage of the nation or region (often linked to political, social, scientific, cultural or economic achievements). Archival and (to a lesser extent) public library collections in Aotearoa, paralleling many other countries, are typically filled with the writings and voices of Pākehā men, and the knowledge, experiences and perspectives of women, gender non-binary/ diverse and non-white subjects are marginalised. ${ }^{17}$ Accordingly, for the purpose of our research it was necessary to go beyond archival collections and seek out other empirical materials to fill the gaps and silence in the historical records. We did this by drawing on newspaper articles, images and, most importantly, oral histories. ${ }^{18}$

Oral histories add the view of eyewitnesses to existing records, providing new or additional information and insights. An oral history provides personal perceptions of individuals who were there, so we can learn not only what happened to people in the past, but the thoughts and feelings they recalled having at that time. Oral accounts are sometimes criticised by scholars who are more comfortable with historical materials that are written down and/or quantifiable for being only (inter)subjective experiential accounts of the past (which are changeable, qualitative and fragmentary). ${ }^{19}$ However, we do not consider the subjective, personal and embodied dimensions of oral histories to be a methodological weakness and instead argue (following on from Brian Williams and Mark Riley) that oral accounts offer historical geographers and environmental historians with a deep source for investigating and situating environmental changes,

15 Cole Harris, 'Archival Fieldwork', Geographical Review 91, no. 1-2 (April 2010): 328-34, doi. org/10.1111/j.1931-0846.2001.tb00487.x; Alan R. H. Baker, Geography and History: Bridging the Divide (Cambridge: Cambridge University Press, 2003), doi.org/10.1017/CBO9780511615818.

16 Sarah De Leeuw, 'Alice through the Looking Glass: Emotion, Personal Connection, and Reading Colonial Archives along the Grain', Journal of Historical Geography 38, no. 3 (2012): 273-81, doi.org/10.1016/j.jhg.2012. 02.003; Ann Laura Stoler, Along the Archival Grain: Epistemic Anxieties and Colonial Common Sense (Princeton, NJ: Princeton University Press, 2010); Sarah Mills, 'Cultural-Historical Geographies of the Archive: Fragments, Objects and Ghosts', Geography Compass 7, no. 10 (2013): 701-13, doi.org/10.1111/gec3.12071.

17 Lachy Paterson and Angela Wanhalla, He Reo Wahine: Maori Women's Voices from the Nineteenth Century (Auckland: Auckland University Press, 2017), 9.

18 Sherna Berger Gluck and Daphne Patai, Women's Words: The Feminist Practice of Oral History (London: Routledge, 2013); Mei-Po Kwan, 'From Oral Histories to Visual Narratives: Re-Presenting the Post-September 11 Experiences of the Muslim Women in the USA', Social \& Cultural Geography 9, no. 6 (2008): 653-69, doi.org/ 10.1080/14649360802292462; Yannis Hamilakis, 'The Past as Oral History', in Thinking through the Body: Archaeologies of Corporality, ed. Yannis Hamilakis, Mark Pluciennik and Sarah Tarlow (New York: Kluwer, 2002), 121-36, doi.org/10.1007/978-1-4615-0693-5_7; Gavin J. Andrews et al., “Their Finest Hour”: Older People, Oral Histories, and the Historical Geography of Social Life', Social \& Cultural Geography 7, no. 2 (2006): 153-77, doi.org/10.1080/14649360600600338.

19 Alan R. H. Baker, “The Dead Don't Answer Questionnaires”: Researching and Writing Historical Geography', Journal of Geography in Higher Education 21, no. 2 (July 1997): 231-43, doi.org/10.1080/03098269708725427; Mills, 'Cultural-Historical Geographies of the Archive'. 
practices, power relations and meaning-making. ${ }^{20}$ In our research, we listened to, transcribed and then analysed the audio recordings of 16 oral histories (two of the oral histories involved two interviewees, bringing the total to 18 interviewees) of individuals who lived in the Waikato and King Country during the late nineteenth and first half of the twentieth centuries (see Table 1). The recordings, made by historians over the last four decades, were held by National Library and Hamilton City Libraries. In addition to the archival materials and oral histories, we also analysed three published memoirs. ${ }^{21}$ Memoirs serve as an important medium for many people, particularly women, whose voices are largely silenced and censored in other written mediums (literary, media and government accounts). ${ }^{22}$ As with oral histories, memoirs provide unique spaces (between experiences and memories) where people can recall their lives and make statements about themselves, their experiences and their values (both in the past and present day). Scholars need to approach such sources with a degree of caution, however, because memoirs often began first as the writings of an individual and were later reworked at a different time and place. Nevertheless, memoirs offer significant insights into the interactions of people with their local environments, and how multiple subjectivities influence people's perceptions of, and actions in response to, the environment. ${ }^{23}$

We employed a thematic analysis, following the six-stage process outlined by Virginia Braun and Victoria Clarke, widely employed within social science and health research, to analyse our collected texts. ${ }^{24}$ Scholars note that thematic analysis is particularly useful in identifying patterns and keywords within data sets. The data analysis process involved familiarisation with the data, followed by an initial coding phase that was conducted manually, the grouping of codes, and finally theme development. The texts provided insights into how gender norms within the Waikato and King Country shaped how individuals perceived themselves, other

20 Emilie S. Cameron, Far Off Metal River: Inuit Lands, Settler Stories, and the Makings of the Contemporary Arctic (Vancouver: UBC Press, 2015); Emilie Cameron, 'Copper Stories: Imaginative Geographies and Material Orderings of the Central Canadian Arctic', in Rethinking the Great White North: Race, Nature and the Historical Geographies of Whiteness in Canada, ed. Andrew Baldwin, Laura Cameron and Audrey Kobayashi (Vancouver: UBC Press, 2011), 169-90; Andrews et al., “"Their Finest Hour”'.

21 One memoir was written by seven siblings from a Pākehā family (the Goodalls), in which they recount their childhood spent growing up on a farm in the Waikato. Another was written by a Pākehā woman (Johnstone) who lived her entire life on various farms within the Waipā River catchment. The final memoir we examined was by a Pākehā man (Spencer Westmacott) who moved from his family farm in Canterbury to establish a farm in the King Country during the decade before the First World War. See Bernice Monrath Johnstone, Not a Pioneer! A Memoir of Waipa and Raglan, 1871-1960: Memories of Bernice Monrath Johnstone of Three Oaks, Whatawhata, New Zealand (Ottawa: P. R. Roberts, 2004); Spencer Westmacott, The After-Breakfast Cigar: Selected Memories of a King Country Settler (Wellington: A. H. \& A. W. Reed, 1977); Hilary Goodall et al., Good God-The Goodalls! The Adventures of a Waikato Farming Family (Hamilton: Larry Goodall, 2018).

22 Maggie Pickering, 'Looking through the Fawn-skin Window: White Women's Sense of Place in the New Worlds of Australia and Canada', Australian Historical Studies 33, no. 118 (January 2002): 226, doi.org/10.1080/ 10314610208596192.

23 Helen Buss, 'Pioneer Women's Memoirs: Preserving the Past/Rescuing the Self', in Reflections, ed. K. Peter Stich (Ottawa: University of Ottawa Press, 1988), 60.

24 Victoria Clarke and Virginia Braun, 'Thematic Analysis', in Encyclopedia of Quality of Life and Well-Being Research, ed. Alex C. Michalos (Dordrecht: Springer, 2014), 6626-8, doi.org/10.1007/978-94-007-0753-5_3470. 
people and their local environmental conditions; which is to say how people's embodied experiences of their environments (be it their homes, gardens, farms, forests, wetlands, rivers, weather conditions and townships) were influenced by particular, spatially and temporally located, gender norms.

One significant risk in conducting thematic analysis, and qualitative research more generally, is that the researchers' own bias and assumptions (conscious and unconscious) about the topic shape what is coded and themed. Following on from other feminist scholars, we reject positivist assumptions of 'universal truth' and instead recognise that our subjectivities inform all aspects of our research. Our decision to embark on a research project that investigates the historical and cultural geographies of the Waipā River catchment, for instance, emerged because of our personal connections to the area. Both authors grew up (at least partly) in the region and are of mixed heritage (Māori/Pākehā/other). Moreover, the second author affiliates (through her mother) to the two major Māori iwi (tribal) groups (Ngāti Maniapoto and Waikato-Tainui) whose rohe (ancestral lands and waters) includes the Waipā River; through her father she traces her whakapapa (genealogy) to Pākehā who arrived in the area to 'settle' and farm in the nineteenth century. Accordingly, we sought to embrace self-reflexivity throughout all aspects of the research process and acknowledge that our life experiences, whānau (family) histories and subjectivities indelibly inform this work. In the rest of this article, we explore our (subjective, partial, but nevertheless insightful) readings of gendered experiences of Pākehā living in the Waikato and King Country.

\section{Results and discussion}

\section{Invading, occupying and transforming the Waikato Delta: 1860s-1900s}

While the Treaty of Waitangi, signed by representatives of various Māori iwi and the British Government in 1840, was meant to guarantee the protection of Māori land and natural resource rights, colonial officials did not honour its terms. ${ }^{25}$ The settlerled government actively sought to appropriate Māori land and to limit the abilities of Māori to exercise rangatiratanga (chiefly authority) over natural resources using military, financial and legal mechanisms. In the Waikato district, the centre of the King Movement (Kīngitanga) that opposed selling land to Pākehā, the appropriation

25 Between July 1863 and April 1864, British military forces (consisting of 12,000 imperial troops, 4,000 colonial solders and several hundred Māori tribal allies fighting against 5,000 part-time Māori warriors) invaded and occupied the Waikato district. James Belich, The New Zealand Wars and the Victorian Interpretation of Racial Conflict (Auckland: Auckland University Press, 2015); Claudia Orange, The Treaty of Waitangi (Wellington: Bridget Williams Books, 2015). 
of Māori land and waterways came first through military actions with a British military invasion. ${ }^{26}$ After the warfare had ended, the government confiscated more than 480,000 hectares of land from Māori, which was allocated to Pākehā men. ${ }^{27}$ A journalist travelling through the Waikato at the time of the invasion called for mass migration of thousands, and tens of thousands, of industrious and necessitous [English] country-men into the fertile plains'. ${ }^{28}$ Such writings, underpinned by settler colonial narratives of untouched nature, positioned the land as lying unused awaiting the arrival of hard-working Pākehā (men) to prune, plant and develop the land into an improved version of rural Britain. ${ }^{29}$ Such a vision of the Waikato floodplains epitomises the Pākehā settler gaze, which was classed, racialised and gendered. ${ }^{30}$ It was a vision that dismissed the legitimacy of Māori occupation, livelihoods and way of life, and imposed mid-Victorian British understandings of human-environment relations and gendered behaviour.

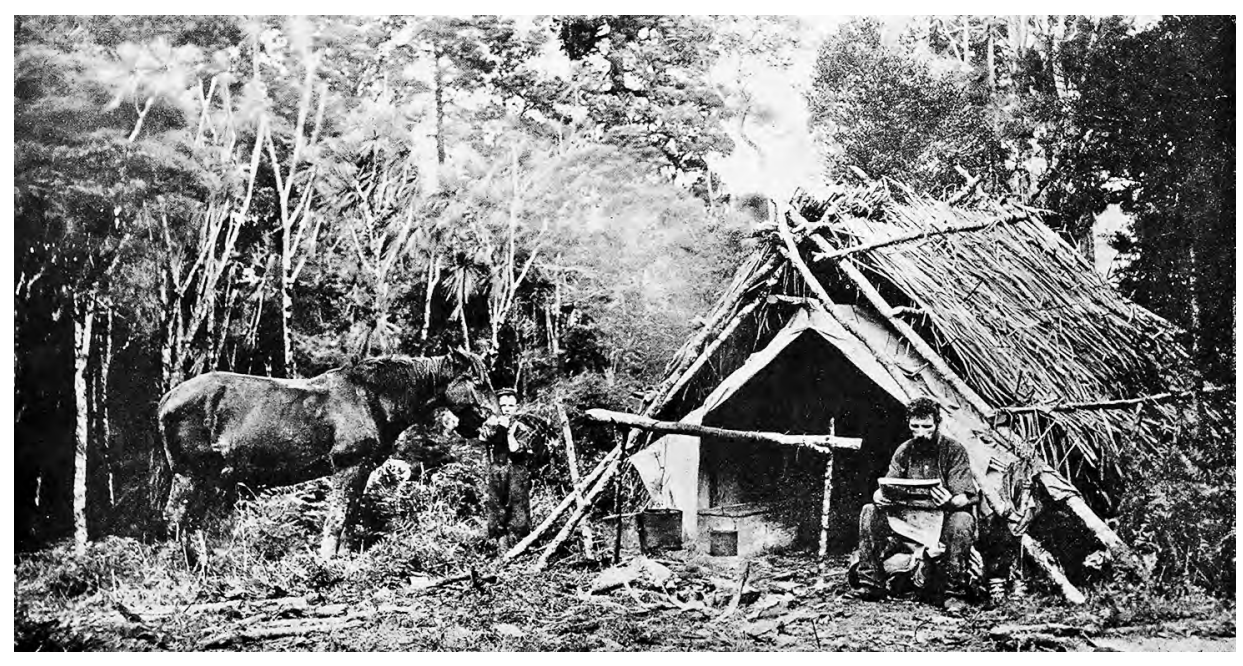

Figure 1: A Pākehā man (described as a 'bushman') and a young boy beside a hut in an unknown location in the 'backblocks' of the King Country (Te Rohe Potāe).

Although the photograph was published in 1919, it is reminiscent of drawings and photographs depicting Pākehā men half a century earlier in the Waikato.

Source: Auckland Libraries Heritage Collections, AWNS.19190102.3.4.

26 [New Zealand Government], 'Proclamation [of Native Lands] Under [the] New Zealand Settlements Act', Daily Southern Cross [Auckland], 6 January 1865, 5; Belich, The New Zealand Wars; Vincent O'Malley, The Great War for New Zealand: Waikato 1800-2000 (Wellington: Bridget Williams Books, 2016), doi.org/10.7810/9781927277577.

27 Māori from the Waikato-Tainui iwi (who supported the Kinngitanga movement) sought refuge with Ngāti Maniapoto in the area that became known as Te Rohe Potae (the King Country). The region remained under the authority of Ngāti Maniapoto until 1882 when the iwi agreed to allow the colonial government to begin to construct a railway line and 'opened up' the area for Pākehā settlers. Michael Belgrave, Dancing with the King: The Rise and Fall of the King Country, 1864-1885 (Auckland: Auckland University Press, 2017).

28 [Anonymous], 'Travels in Waikato-Continued. 5 September 1863', Taranaki Herald, 5 September 1863.

29 Russell McGregor, Imagined Destinies: Aboriginal Australians and the Doomed Race Theory, 1880-1939 (Carlton, Vic: Melbourne University Press, 1997).

30 [Anonymous], 'Travels in Waikato'. 
The colonisation of the Waikato (as elsewhere in Aotearoa) was founded on specific beliefs about what the environment should look like, how it should be used and who should be allowed to derive benefits from it. ${ }^{31}$ The scholar Jill Casid highlights how colonial plantations and farms across the European colonial world justified and glorified patriarchally organised and controlled agricultural production and heterosexual reproduction as the necessary bases for family and for national and imperial stability, peace and prosperity'. ${ }^{32}$ At the heart of Pākehā imagined geographies of the Waikato was the farm (a constructed and carefully cultivated site of pastoral agriculture or horticulture), a place where 'nature' was improved through the intervention, in Casid's words, 'of "man" that functioned as both the material impress and reproducing sign of empire'. Throughout the late nineteenth and first decades of the twentieth centuries, Pākehā farmers (a category that was exclusively used in reference to men) in the district wrote how the biota and climatic conditions were tests of their manliness, something they needed to battle against and ultimately command. Pākehā men's abilities to endure living 'rough' (in tents, a whare or slab huts) in a harsh environment, and employ their physical strength and mental resilience were some of the key features of ideal rural manliness. The genesis myth, like those recorded by the historian Katie Holmes in her history of the Mallee in Victoria, Australia, is found throughout the history of farming in the Waikato and King Country: hard-working Pākehā men (pioneers or settlers) who cleared the forests, drained the 'swamps', survived floods and droughts, and ultimately created thriving agricultural communities. ${ }^{33}$ The common tropes of stories (told and retold within families, schools and histories) about the region emphasise Pākehā men's abilities to withstand harsh environments (the 'forces of nature' such as fog, floods, drought and peat fires) through the application of their bodily strength and courage. In doing so, these men enacted the 'great transformation of the land' from inhospitable, unproductive (indigenous) wastelands into productive

\footnotetext{
31 Geoff Park, Effective Exclusion: An Exploratory Overview of the Crown's Actions and Maori Responses Concerning Flora and Fauna, 1912-1983. Report Prepared for the Waitangi Tribunal (Wellington: Legislation Direct, 2001); Parsons and Nalau, 'Historical Analogies as Tools in Understanding Transformation'; Holland, Home in the Howling Wilderness.

32 Jill H. Casid, Sowing Empire: Landscape and Colonization (Minneapolis, MN: University of Minnesota Press, 2005), xxii.

33 Farmers' Union report from 1903 as well as the quotation from the Farmers' Union Advocate are cited in P. S. O'Connor, The Growth of New Zealand Farming, 1890-1918 (London: Heinemann Educational Books, 1970), 18; Lieutenant-Colonel Chesney, 'The Future Home of the Waikato Settlers', Daily Southern Cross, 8 February 1866; Patrick Corray, 'The Floods in the Waikato', Auckland Star, 3 February 1893; G. T. Wilkinson, Otorohanga, 'Natives Ask for Further Relief on Account of Losses by Waipa Floods', 26 July 1893. R24563475, ACGS 16211, J1 505/J, 1893/1155. Archives New Zealand, Wellington; [Anonymous], 'Dismal Swamp', Waikato Independent, 30 September 1909; [Anonymous], 'Kawa Drainage Board', King Country Chronicle, 14 January 1909; [Anonymous], 'Waikato Swamps and Swampers', The Press [Christchurch], 19 August 1887.
} 
pastoral properties that formed part of rural communities. ${ }^{34}$ Alongside drainage efforts, the sowing of grasses (see Figure 2), the building of houses and roads and the introduction of livestock, the planting of introduced species of exotic flora and fauna was positioned as a key way Pākehā men could correct the perceived environmental deficits of the existing landscapes and waterscapes and ensure their 'dominion' over nature. ${ }^{35}$

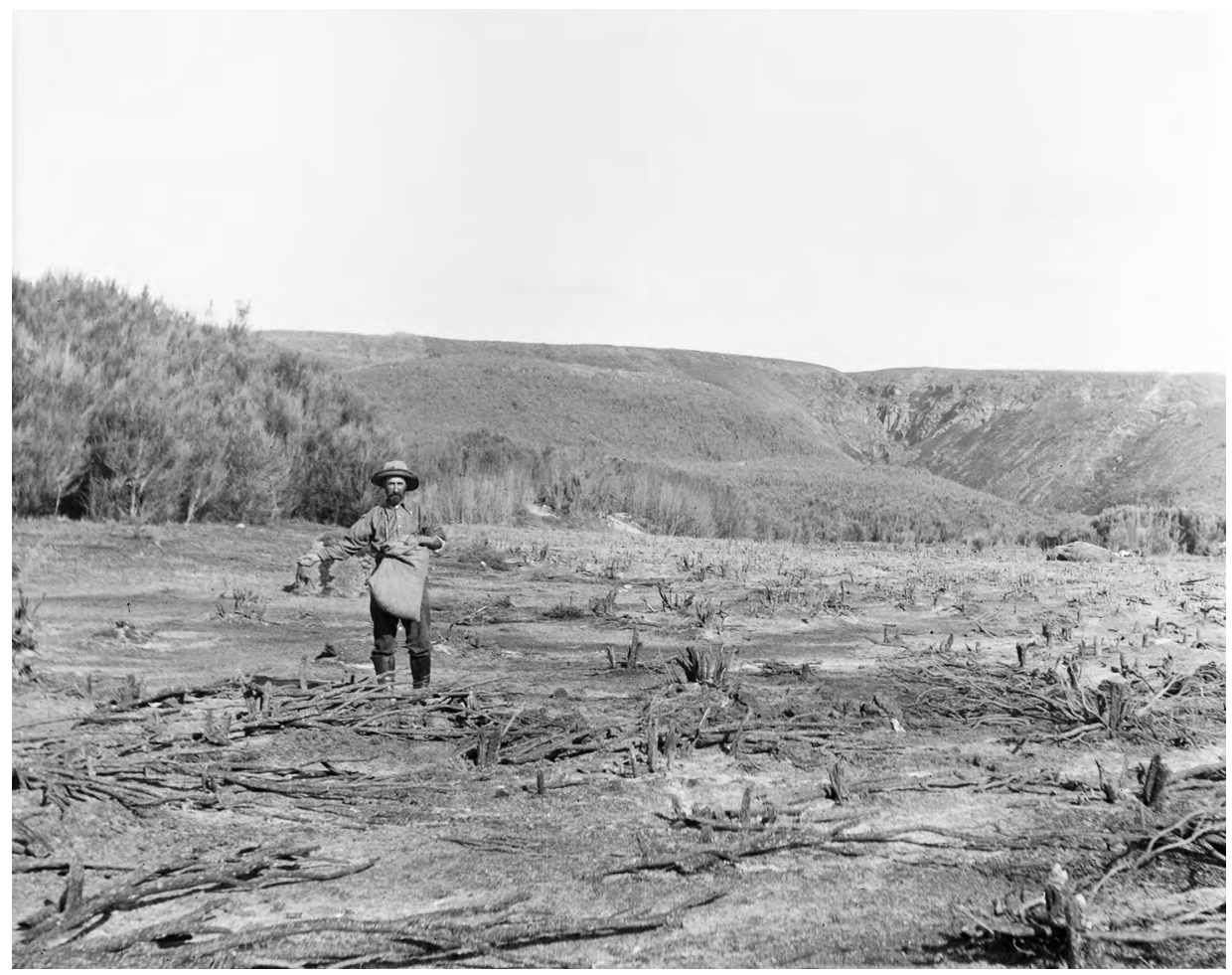

\section{Figure 2: A Pākehā man standing in a burnt-out section of land (somewhere in the King Country in the early twentieth century), sowing grass seeds.}

Although there was a small amount of logging activity in the Waikato and King Country districts, the majority of indigenous vegetation (both forest and shrub) was cleared using fire.

Source: Auckland Libraries Heritage Collections, 2-V448.

34 Waitanguru Jubilee Committee, Waitanguru: The Great Transformation: A Collection of Memories Depicting Optimism, Disaster and Progress of the Waitanguru, Mangaotaki, Ngapaenga and Mairoa Districts, ed. S. B. Frederikson and Ron Cooke (Taumaranui: Published for Waitanguru Jubilee Committee by C \& S Publications, 1990), 9; Oral history (Vicki Jones interviewing Bruce Henderson) records similar ideas. See Vicki Jones, Bruce Henderson, Cassette, 22 July 1996. OHCOLL-0635/09. Alexander Turnbull Library, Wellington; such ideas also have been found by social scientists in their studies of contemporary rural communities. See Berit Brandth, 'Rural Masculinity in Transition: Gender Images in Tractor Advertisements', Journal of Rural Studies 11, no. 2 (1995): 123-33, doi.org/10.1016/07430167(95)00007-A; Lise Saugeres, 'The Cultural Representation of the Farming Landscape: Masculinity, Power and Nature', Journal of Rural Studies 18, no. 4 (2002): 373-84, doi.org/10.1016/S0743-0167(02)00010-4.

35 James Beattie, 'Environmental Anxiety in New Zealand, 1840-1941: Climate Change, Soil Erosion, Sand Drift, Flooding and Forest Conservation', Environment and History 9, no. 4 (November 2003): 379-92, doi.org/ $10.3197 / 096734003129342881$. 


\section{Gendered tales of battling, becoming and dislocation: 1860s-1930s}

The voices of women often barely registered through this hegemonic narrative of Pākehā masculine place-making, the few written records from the Waikato and King Country we located in the archives offering brief glimpses into wider histories. ${ }^{36}$ The letters women wrote to government officials or newspapers, as well as reflections recorded in the memoirs and oral histories (created later in their lives and recalling their memories through the prism of present-day concerns) we located, do, however, shed light on women's daily lives, domestic life and labour, and broader concerns. One letter written by a Pākehā woman living in the town of Cambridge (located alongside the Waikato River) in April 1866 to a newspaper recounts her and others' difficulties in obtaining the basic 'necessities of life' (including clothes, bread and soap). In line with hegemonic femininity ideals that positioned women as carers and as physically vulnerable (in comparison to men's imagined physical strength and resilience), the letter describes her fears for her children's and others' lives: 'I find myself in a fearful state, with winter coming on, and every-thing wanting ... if there is no assistance given the women and children may manage to live on vegetables but the young infants surely die'. ${ }^{37}$ The historian Maggie Pickering observes that 'settling' and taming the 'wilderness' typically represent women within the confines of the domestic spaces (of house and garden). In settler colonial societies, this frontier mythology often depicts the bush, forest and wetlands as threats to the well-being of white women, necessitating the retreat to the safety of home (the garden, veranda or house). In the 'backblocks' - the Aotearoa version of the frontier-Pākehā women often recalled the bush and wetlands as being places of isolation, where they felt they did not belong at present, but could do so if they enacted the correct behaviour and practices (directed at environmental transformation).

Within the domestic sphere, which encompassed the house and gardens, Pākehā women developed a variety of practices to negotiate and mitigate the 'smellscapes' of wetlands and 'improve' the landscape of the Waikato. In addition to planting trees (typically deemed a masculine task), local and international literature (much of which was written by women under pen names) emphasised the critical role women could play in beautifying and purifying the fever-inducing wetlands and creating healthy homes. Scientific discoveries about the role of plants in generating oxygen were widely reported in international and domestic newspapers and journals, and used to support existing miasmatic understandings of disease (with femininity

36 Bradford Haami, Pütea Whakairo: Mãori and the Written Word (Wellington: Huia in association with the Ministry for Culture and Heritage, 2004); Paterson and Wanhalla, He Reo Wahine.

37 Cited by Dench, 'Invading the Waikato: A Postcolonial Re-View', 45. 
closely aligned to domesticity and cleanliness). ${ }^{38}$ Newspapers instructed that women living in 'marshy districts or places infected' with bad air (miasmas) 'should surround their dwellings with seeds of the most odorous flowers' ${ }^{39}$ In 1875, one unnamed columnist who used the pen name 'The Queen' (which suggests the writer was a woman) informed readers that certain flowers, including sunflowers, lavender and narcissi, were 'endowed with health-preserving properties' and were 'the most valuable of sanitary agents'. The cultivation of flowers in one's garden was both a 'delightful and humanising' act to enrich the aesthetic appeal of the landscape, but also a way in which to 'confer a positive benefit on society [which is] so great that it can hardly be overrated'. ${ }^{40}$ Indeed, Pākehā women often narrated the establishment of gardens (including flower beds, vegetable gardens and orchards) as the foundation of their efforts at homemaking; their so-called 'becoming landscape' wherein they could enact their own ecological transformations of 'wild' and unknown spaces into cultivated and defined places. ${ }^{41}$

Pākehā women recorded with a tremendous sense of accomplishment and joy their efforts (or those of their mothers, sisters, daughters and daughters-in-law) in creating something (gardens) out of nothing (the 'backblocks'). Likewise, Pākehā men spoke of their pride that their mothers and wives had created beautiful gardens on their farms (which were the envy of others in the district). Attractive flower beds, nicely mowed lawns and clipped hedges were all markers of particular cultural norms (class, ethnicity and gender) tied to rural hegemonic femininity. As Mary Meyer recounted in her oral history, she and the other girls in her local area were taught at home and at school about their responsibilities for maintaining gardens. At her school, the girls were required to maintain the school gardens, which consisted of exotic plants, yearround. Sometimes a few native trees remained, but emphasis was placed on ensuring that the indigenous fauna was surrounded by introduced species (hemmed in on all sides).$^{42}$ As Shirley Finlayson recalled, her mother-in-law's garden in 1914 consisted of a 'huge laurel hedge ... lots of good-quality shrubs [and] lovely camellias', with the garden stretching around the house including lots of colourful flowers, and one 'very large rimu' by the front gate. ${ }^{43}$ Once she and her husband took over his family's farm, Shirley extended the existing garden and added large numbers of expensive exotic plants (including cherry trees, maples, rhododendrons and azaleas) to bring colour, shade and structure to the garden. She sought out experts from the local

38 [Anonymous], 'Health from Flowers', Daily Southern Cross, 1 July 1875; [Anonymous], 'Health in Perfumes',

The Press, 22 February 1873.

39 [Anonymous], 'Health in Perfumes'.

40 [Anonymous], 'Health from Flowers'.

41 The term 'becoming landscape' is used by Kuntala Lahiri-Dutt to refer to hybrid colonial landscapes. See Kuntala Lahiri-Dutt, 'Beyond the Water-Land Binary in Geography: Water/Lands of Bengal Re-Visioning Hybridity', ACME: An International Journal for Critical Geographies 13, no. 3 (2014): 505-29.

42 Vicki Jones, interview with Mary Meyer, 1996. Casette, OH1018. Hamilton Libraries Oral History Collections.

43 Jones interview with Meyer. 
horticultural society for advice, and even commissioned a landscape architect to design her herb garden. Indeed, many Pākehā women and men spoke about how women were judged by their neighbours because of their gardens. ${ }^{44}$ Women attained higher social standing within their communities based on the size and perceived beauty of their gardens, which highlights how class intersected with gender norms. Not only did women compete every year at their local agricultural and pastoral (A\&P) shows for the title of 'best gladioli, gerberas, portulaca, and a host of other colourful flowers', but they and their neighbours made these same assessments (about whose gardens were the best) in their day-to-day lives. ${ }^{45}$

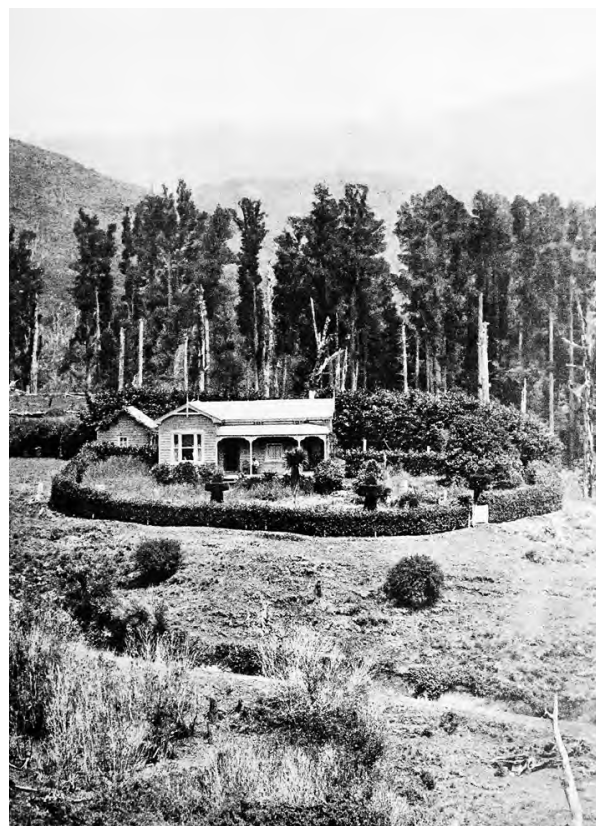

Figure 3: A farmhouse surrounded by its garden somewhere in the King Country.

Source: Auckland Libraries Heritage Collections. AWNS-19191016-35-1.

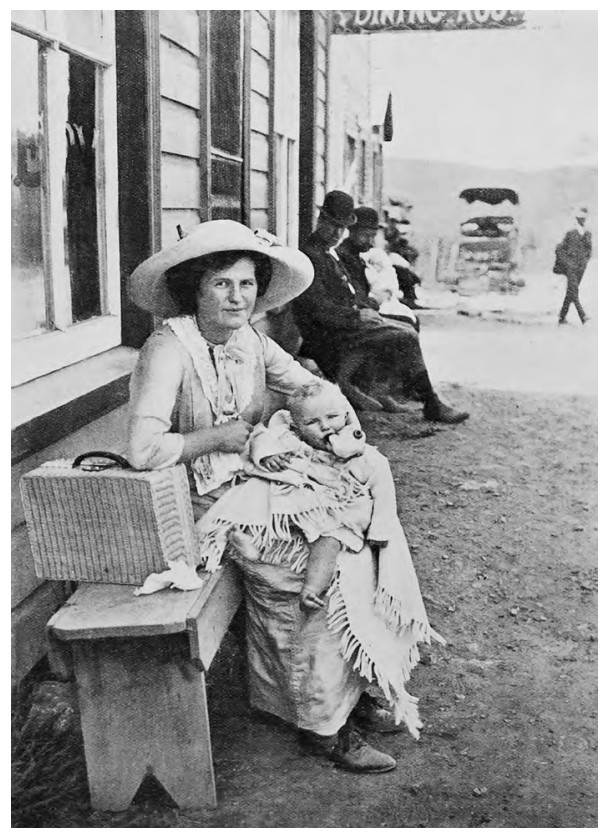

Figure 4: A Pākehā woman with a baby awaiting a change of horses at Piopio, King Country, 1914.

Source: Auckland Libraries Heritage Collections, AWNS-19140416-42-2.

The 'becoming landscape' recounted by many Pākehā women in the records we examined was more heavily centred on feelings of dislocation and isolation than that described by men. ${ }^{46}$ Farms were sometimes located several hours' horse ride from the nearest town, which served to engender specific difficulties for women to travel, access basic social services and socialise with others. Pregnancies and childcare responsibilities, as well as inequitable power dynamics within

44 Ibid.

45 Goodall et al., Good God - The Goodalls!

46 Johnstone, Not a Pioneer!, 24. 
households, meant women faced gender-specific restrictions on their ability to travel (see Figure 4). Many women, including Margaret Macky, joined the Women's Division of Federated Farmers (which began to operate in the district in the late 1920s) as a way to ease their feelings of social isolation and allow them the opportunity to converse with other women. These feelings of dislocation and anxieties were mixed with pride that extended beyond sentimental constructions and narratives of home, such as hearth, safety, community, roots and belonging, to encompass the need to systematically transform the landscapes of the Waikato and King Country (from forests and wetlands to grasslands, parks, towns and gardens). ${ }^{47}$ These actions to transform environments also sought to erase the Indigenous presence within the sociocultural and biophysical landscapes and waterscapes of the Waikato and King Country.

\section{Women as helpers not farmers: Gender behaviour and marginalised femininities: 1890s-1930s}

In their oral histories and memoirs, Pākehā women, including Florence McGovern, Ethel Booth and Ngaire Featherson, all of whom lived in the Waikato backblocks during the 1860s-1930s period, depicted themselves as actively participating in and supporting the environmental changes that took place on their farms. This included the clearance of forests, drainage of wetlands, introduction of new plants and animals, and creation of gardens and homes. Bernice Johnstone, who lived on a series of sheep and dairy farms during her time in the Waikato (1872-1960), recalled that for her the shearing season (each October) was the 'busiest time of the year'. Her responsibilities at that time of year included the preparation of groceries for the family and shearers; making meals for her family, as well as the shearing gang (they always employed Māori shearers, who were overseen by a Pākehā farm manager); milking the cows; feeding the pigs and calves; washing clothes and dishes; feeding and bathing her youngest children; cleaning and other housework; and chopping the firewood. ${ }^{48}$ Overwhelmingly, Johnstone and other women narrated their involvement in accordance with the ideal of a 'helpmate' or assistant rather than a key actor or a farmer themselves. Yet oral histories and photographs of the time highlight that Pākehā women were actively engaged in farming and logging work and that their labour was not tokenistic but rather central to the operations and success of agricultural projects (which were part of environmental transformations) (see Figures 5 and 6).

47 Ibid., 15.

48 Ibid., 134-5. 


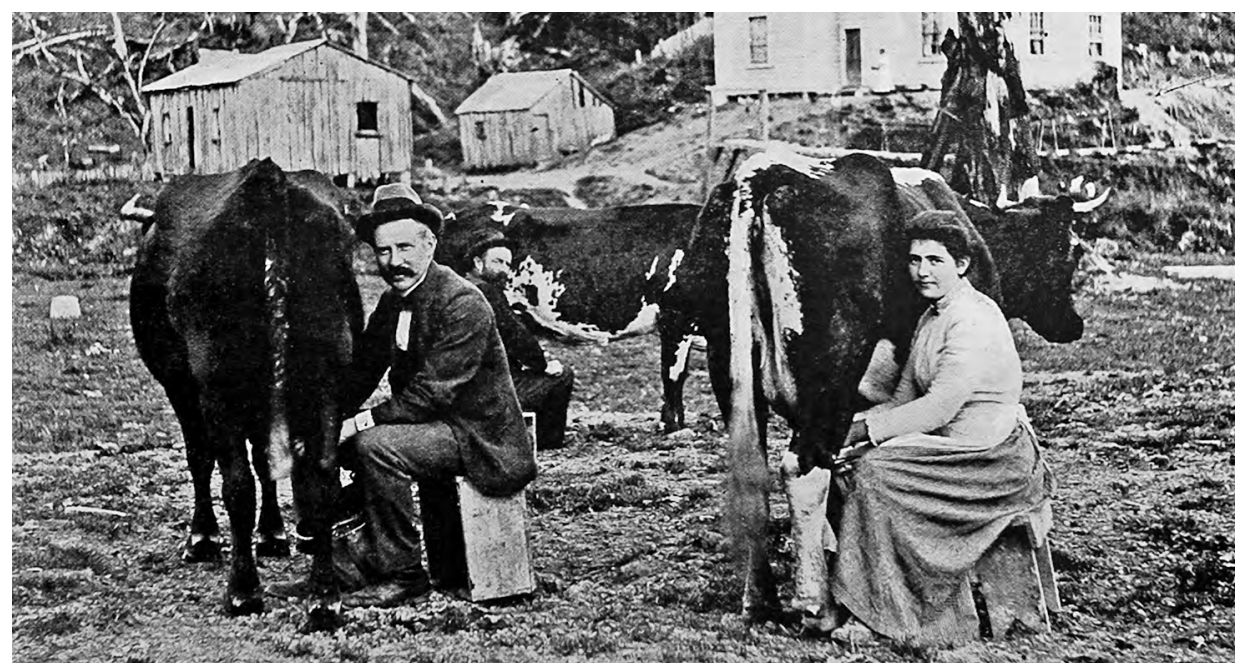

Figure 5: 'Dairying in the Backblocks', taken in the King Country, 1901. Originally published in Auckland Weekly News, 19 April 1901, 3.

Source: Auckland Libraries Heritage Collections, AWNS-19010419-3-4.

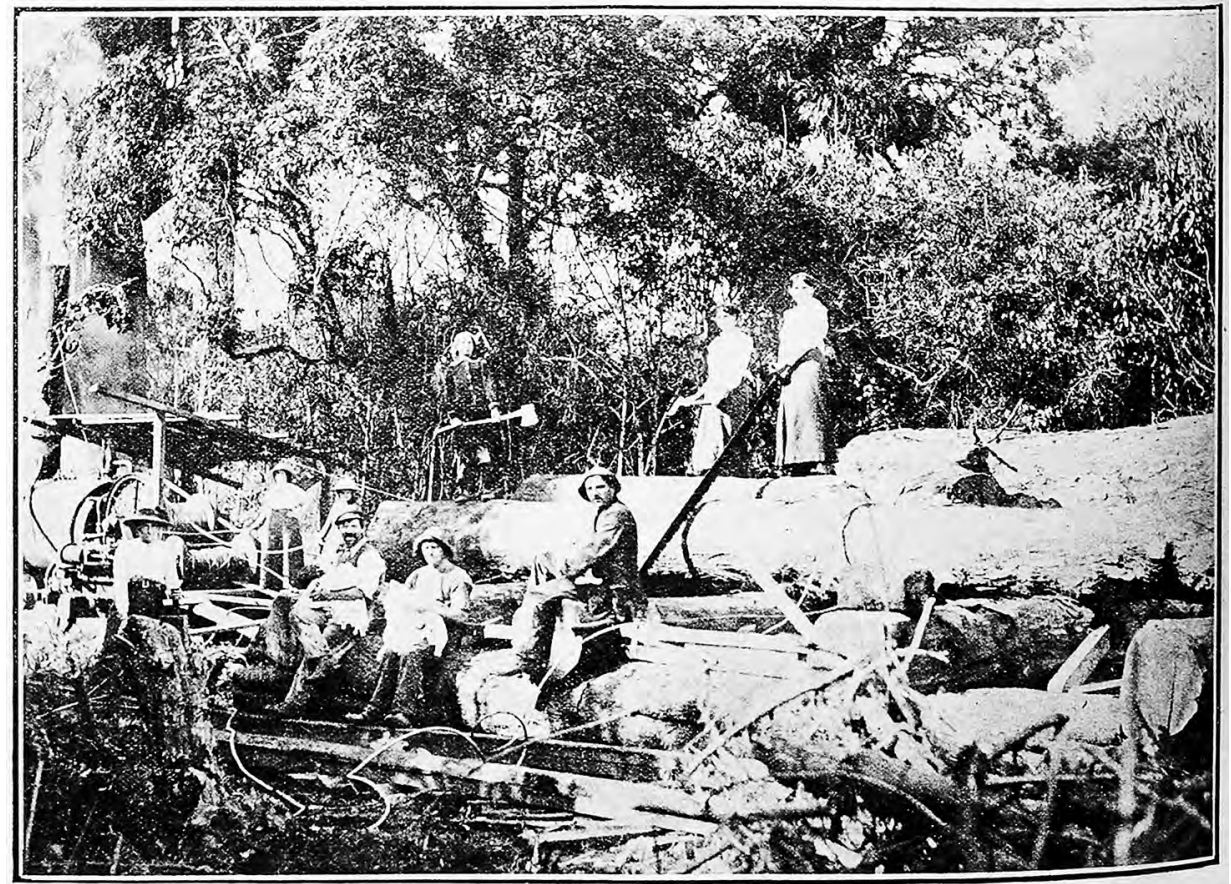

WOMEN PREPARED TO TAKL A HAND IN BUSH WORK. NOW THAT THE SECOND DIVISION MEN ARE BEANG CALLED TO THE cOLOUTS SCENE ON A FARM IN THL KING COUNTRY. NORTH Figure 6: Pākehā men and women engaged in logging in the King Country in 1918.

The original title (shown at the bottom of the image) emphasised that women were only undertaking logging work as a consequence of men being involved in the First World War.

Source: Auckland Libraries Heritage Collections, AWNS-19180523-38-5. 
Mary Meyer, who was born in 1902 on a sheep farm in the Waikato before moving to a dairy farm near the Waipā River, later described herself as having been a 'real land girl' when she was a child and teenager. She described how her entire childhood was spent helping her father 'with whatever he was doing' on the farm, including 'building oat sacks', feeding the horses, 'rolling the fleeces', taking care of the sheep and making the hay. ${ }^{49}$ She added that when it was time to make hay on the farm, her entire family (mother, father, sister and she) would all be involved in the process. However, she and the other women were never expected to do the 'the heavy work'; this was left to men (her father and neighbouring farmers who came to assist him). Meyer observed that, in comparison to other Pākehā 'homesteads', her childhood home was 'washed less often', and her mother's cleaning regime was 'dependent on what work needed to be done on the farm'. In making this brief statement, Meyer acknowledges that women's lived experiences rarely perfectly aligned with the socially expected gender norms of the time, with the performances of hegemonic femininity (most notably those tied to domesticity) often imperfect. When Meyer married and went to live on a dairy farm, she continued to frame her responsibilities as the assistant to her husband, the farmer, and positioned herself within the domestic space. Yet, at the same time, she continued to be involved in the dayto-day activities of farming (most notably milking the cows) and acknowledged that she missed being a real 'land girl' and being out on the land every day and caring for her sheep (she declared she did not love cows the same way as she did sheep). ${ }^{50}$ Her farm work, however, was positioned as secondary (not her real work) to her other tasks, including preserving fruit, maintaining the garden, cleaning the house, cooking meals for the family and various farm workers, and taking care of the children. She also joined the Women's Division of the Farmers' Union (now Federated Farmers) and engaged in the organisation's activities, including entering baking and flower-arranging competitions. Herein rests the multiple contradictions within these histories ('her-stories'). The women frequently assign themselves to the role of supporting actors in their own memoirs, life histories and publications in a way that fits them within the gender hegemony (whereby women are positioned as secondary to men). The women told stories that not only undervalued the importance of their labour to the financial viability of the farming operations, but also dismissed or ignored the pleasure they gained from working on the land (be it cutting down trees, making hay or caring for livestock). Indeed, for these women, stepping outside the confines of domesticity allowed them to form connections to land, to animals and to themselves, which in turn reduced their feelings of isolation and dislocation, as well as their environmental anxieties about landscapes and waterscapes of the Waikato.

49 Jones interview with Meyer.

50 Ibid. 
Similarly, the oral histories of Pākehā men, recalling their lives spent on Waikato farms from the 1920s to the 1980s, repeatedly spoke about how they never considered that 'a lady [should do] any hard farm work' (as Bruce Henderson stated in his oral history). Henderson grew up on a farm outside Hamilton in the 1930s and 1940s and witnessed his mother milking the cows, helping with haymaking, feeding the farm dogs and working late into the night. Yet none of these activities were considered part of her 'normal duties'. ${ }^{51}$ When Henderson himself later married (in the 1960s), he did not 'expect [his] wife to help outside' (on the farm). Rather, he spoke of how he and his wife occupied separate domains (her place was inside the garden gate and his was outside the gate). Henderson spoke with pride of how his 'mother and [his] wife got [to create] really nice gardens and kept the [house] well', which articulated the gender and class dimensions of hegemonic masculinity and femininity. ${ }^{52}$ Such notions of femininity were an expression of particular culturally situated gender norms traceable to the early nineteenth century and the emergence of the cult of domesticity in Britain and its settler colonies, which charged women with responsibility for their families and their nation's moral and physical wellbeing. By the time the Waikato was being invaded and colonised, this ideology was firmly engrained in the belief systems of many of Pākehā settlers in the region. Accordingly, it was considered the duty of Pākehā women to create and maintain tidy, clean and ordered private (domestic) spaces to provide security for their family and the wider (settler colonial) community. ${ }^{53}$ Even if the daily lives of Pākehā women living in the backblocks bore little resemblance to the ideals of middle-class (decidedly urban) British Victorian domesticity, such imaginings held considerable cultural value. Moreover, domesticity described gender norms rather than specific actions that women should take, allowed considerable elasticity in terms of meaning and application (as Julie Jeffery observes in the rural US context), and ensured its durability across temporal and spatial contexts. More than a century later, such classifications of rural femininity involving labour that took place within domestic and private domains (within the boundaries of the homestead and not the farm, forest or town) continued to be articulated in the early to mid-twentieth century Waikato and King Country. ${ }^{54}$ In particular, rural hegemonic femininity continued to be popularly narrated as a wife and mother who devoted her time to ensuring her husband, children and wider family were fed, clothed and cleansed. Her home environment was also well-ordered, sweet-smelling and adorned with attractive artefacts (flowers, shrubs, box hedging), which was a testament to her capacities (like her husband's) to command and control nature.

\footnotetext{
51 Jones interview with Henderson.

52 Ibid.

53 Barbara Brookes, A History of New Zealand Women (Wellington: Bridget Williams Books, 2016), 523, doi.org/ $10.7810 / 9780908321452$.

54 Bridget Hill, Women, Work and Sexual Politics in Eighteenth-Century England (London: Routledge, 2005), doi.org/10.4324/9780203986318; Bridget Hill, Eighteenth-Century Women: An Anthology (London: Routledge, 2013), doi.org/10.4324/9780203104071.
} 
In reality, the lives of many women (particularly working-class Pākehā and Māori women) did not live up to the ideals of hegemonic rural femininity. Many women actively participated in what was then deemed masculine work, such as land clearance and drainage, and recalled those activities were more important (and more enjoyable) than housework. In her oral history, Florence Emily McGovern recalled her childhood and early adulthood spent on farms in the Waikato between 1902 and 1919. At the age of 14, she left school and worked on her family farm at Tuhikaramea (south-west of Hamilton). Her entire family, including her mother, were all involved in general farm work. McGovern's mother, she remembers, was someone far more comfortable doing 'anything at all outside' than being inside undertaking domestic activities. In contrast to the rural femininity ideal in the early twentieth century, McGovern declared that, in her family home, housework 'never worried us much ... all our time was needed outside on the farm' and she continued (at the age of 84 years) to view it as a pointless task. ${ }^{55}$ She recalled her childhood and teenage years spent cutting down 'tea-trees' (manuka, Leptospermum scoparium), digging out tree stumps, constructing drainage canals, milking, dragging out cows stuck in ditches and cutting firewood. After the trees were cut down, the remaining vegetation was burnt off and the cleared area planted with exotic trees and grasses. McGovern recalls with pride how the 'unimproved' and 'very swampy peaty' landscape was 'brought in' through her own and the rest of her family's transformative actions. Ultimately, their family farm was remade into 'jolly good ... clean ground' which '[y] ou could run a mower over every bit of'. ${ }^{56}$

Pākehā women who undertook farm work were often criticised, with their behaviour deemed unfeminine. Men wrote about how the bodies of women who undertook 'hard work' (farm labour) were 'gaunt', unattractive and rendered 'old before their time'. ${ }^{57}$ Such criticisms were often made by individuals (typically Pākehā men but also some women) from wealthier backgrounds (middle- to upper-class) who possessed the financial resources (unlike working-class households) to employ others to work as farm labourers or domestic servants. Those employed were often Māori individuals or entire families dispossessed of their lands and in desperate need of employment, as shown in the two contrasting photographs of Māori and Pākehā families in hop fields in the King Country (see Figures 7 and 8). ${ }^{58}$ The writings differentiated between the supposedly inherent capacities of (Pākehā) women's bodies to undertake so-called hard labour 'taming' nature (as vulnerable and lacking the physical strength needed) and those of men's bodies (as strong and resilient). Such discourses served to justify men's domination over women, to locate features

55 Jeff Downs interview with Florence Emily McGovern, 'A hard life: Reminisce[nce]s 1902-1919', 18 February 1986. Cassette. Hamilton City Libraries Oral History Programme.

56 Downs interview with McGovern.

57 Westmacott, The After-Breakfast Cigar, 105.

58 John Clark, ed., I Remember, I Remember: Memories of Margaret Clark Nee Levien (Taradale: Duplex Design, 1997), 14. 
of hegemonic masculinity outside the reach of women (including their abilities to seek to control 'nature') and to denigrate non-hegemonic (pariah) femininities (often working class and/or non-white) of those who engaged in labour outside the domestic sphere. In this way, multiple subjectivities (gender, class, race) intersected and operated within the rural landscapes of the Waikato and King Country wherein hegemonic masculinity (Pākehā, middle class, heterosexual) was at the apex of the social order. ${ }^{59}$

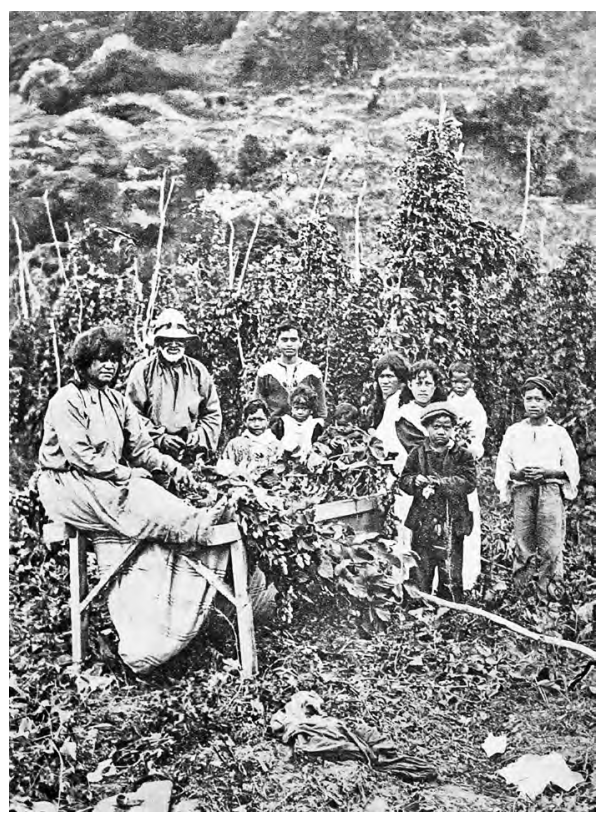

Figure 7: Māori whānau picking hops in 1907 (King Country).

It was commonplace in this time period for entire Māori whānau to travel and work together. The consequence of colonial violence and dispossession was that Māori not only lost the majority of their lands in the Waikato and King Country but also their capacities to practise their customary subsistence livelihood activities. Accordingly, Māori were dependent on seasonal agricultural work.

Source: Auckland Libraries Heritage Collections, AWN-19070328-1-4.

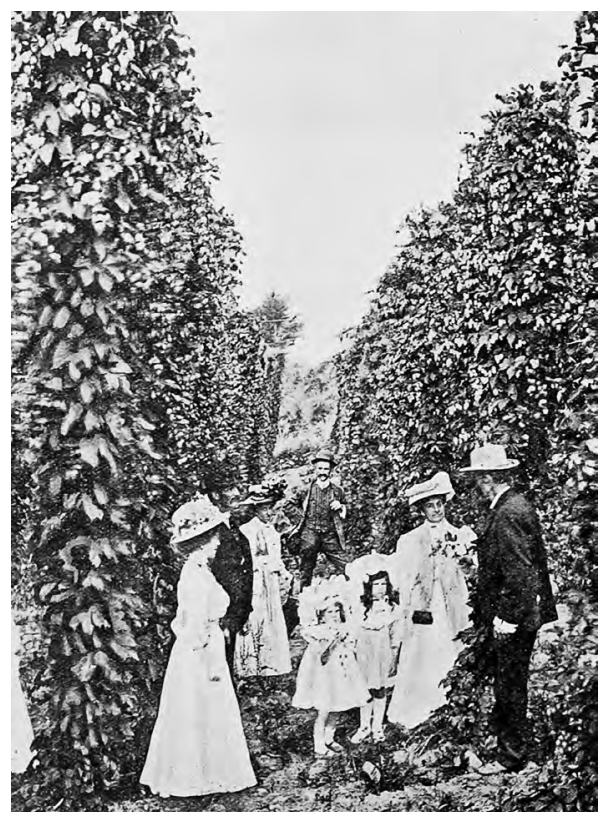

Figure 8: A group of Pākehā men, women and children visiting hops growing in the King Country in 1909 wearing formal clothes (in contrast to Figure 7), which indicates they were not directly engaged in the labour of picking the hops but merely enjoyed the products (beer and money) derived from others' labour.

Source: Auckland Libraries Heritage Collections, AWNS-19090617-14-5.

59 Mimi Schippers, 'Recovering the Feminine Other: Masculinity, Femininity, and Gender Hegemony', Theory and Society 36, no. 1 (March 2007): 91, doi.org/10.1007/s11186-007-9022-4. 


\section{Women's (in)capacities to make (financial) decisions}

Pākehā women's capacities to participate in decisions related to their daily lives and livelihoods were often severely constrained by gender hegemony and legal restrictions. Johnstone writes that one of the key hardships of the 'home-making venture' for her was feelings of powerlessness; despite her pre-marriage life as a teacher and her income having helped to supply the deposit for the farm, her life (she recalled in her 70s) was 'dictated' by her brother-in-law ('Cam'). Whenever her husband was away working on tree-cutting and road-making contracts, which supplemented the farm's limited income, her brother-in-law (who jointly owned the property) 'took the place of "man of the house" ${ }^{60}$ After her husband's death in 1915, Johnstone was forced to move with her children from her family's farm, as her brother-in-law wanted to subdivide the property. Eventually, she and her adult sons 'bought 145 acres of rough, uneven, and steep country on the banks of the Waipa'. As a widow in her 40s and 50s, she was forced to start the 'home-making venture' again, with the construction of a house and planting of a garden, as well as the clearing of scrub, and the drainage, ploughing and grassing of the land. ${ }^{61}$

The contribution of women such as Johnstone and others to the creation and operation of farms contrasted with the inequalities in decision-making power, access to finance and inheritance patterns amongst men and women. Henderson, for instance, recalled that his mother did not inherit any of her family's several farming properties in the Waikato, and instead all the properties were divided amongst her male relatives (brothers, uncles, cousins and sons). Although the passing of the Married Women's Property Act in Aotearoa in 1884 meant that, upon marriage, a woman no longer negated her legal personhood and she was legally able to retain property and hold cash of her own, few married women did so. Indeed, many rural Pākehā women spoke in their oral histories about the stresses that persisted within their lives due to the legal regime and social norms, which meant few of them, even in the mid-twentieth century, could access money. For these women, their bank accounts and property were in their husbands' names, and even if they wanted to open their own bank account, bank managers refused their requests. Accordingly, Pākehā men were far more likely than women to inherit property and assets amongst farming families throughout the century. ${ }^{62}$ Few Pākehā women in rural areas actually owned property or brought with them large financial holdings in their own right. ${ }^{63}$ Inheritance practices were not simply based on the assumption that

\footnotetext{
60 Johnstone, Not a Pioneer!, 119.

61 Ibid., 158.

62 Jim McAloon, 'Family, Wealth and Inheritance in a Settler Society: The South Island of New Zealand c. 1865-

c. 1930', Journal of Historical Geography 25, no. 2 (1999): 206, doi.org/10.1006/jhge.1999.0114.

63 Ibid., 208-9.
} 
Pākehā women were incapable of running farms or managing finances, but also on deliberate policies and a legal tradition focused on passing family wealth (meaning the traditional male-headed nuclear family) on to the next generation (of men). ${ }^{64}$

Rural hegemonic masculinity in Aotearoa was premised on the idea that the creation and maintenance of farming properties was dependent solely on the labour (and managerial skills) of Pākehā men. These men exercised their muscle, controlled land/water/biota or other people, and in doing so performed manliness in order to accumulate material wealth. These avenues of self-development and profitability were not offered to Pākehā women or to the colonised peoples, even when they undertook exactly the same activities.

\section{Intersections of gender hegemony with those of race and class}

Gender norms were (and still are) culturally and spatially constituted. Our research has identified specific characteristics associated with the performance of rural femininity and masculinity. While gender norms were something individuals living in the Waikato and King Country performed, the consideration of acceptable gender behaviour was the focus of ubiquitous discourses. The contours of suitable gender behaviour were disseminated through social institutions, the legal regime, the educational system, popular culture and religious teachings, and became dominant to the point of naturalisation. It was through these processes of naturalisation and internalisation that specific types of gender norms became hegemonic. Hegemonic masculinity within the rural Waikato and King Country involved the configuration of gender practices that took for granted the privileged position of Pākehā men as farmers, property owners and controllers of nature, money and the labour of others (those deemed subordinate, including both women and Indigenous peoples). Hegemonic femininity, as the work of Mimi Schippers demonstrates, was the ideal of Pākehā womanly behaviour and operated as a complementary relationship to

\footnotetext{
64 In contrast, Māori gender norms prior to colonisation markedly differed from those of British and other European societies. Both men and women worked on the land and were involved in cultivating and harvesting foods. While there was gendered division of labour, it varied across tribal areas, and Māori women occupied a variety of positions within their communities, with rank (ranging from slaves to chiefs) often more important in determining what activities people could participate in than gender. However, settler colonialism substantively reduced Māori women's communal land rights and authority, with the Native Lands Act of 1865, which abolished Māori land rights through matrilineal descent. Although the Native Lands Act of 1869 did contain a clause that allowed Māori women some degree of legal capacity, and women participated in Native Land Court cases, Māori women's legal rights regarding their bodies, children, lands and finances all diminished as a consequence of settler colonialism. McAloon, 'Family, Wealth and Inheritance in a Settler Society'; Brookes, A History of New Zealand Women; Angela Wanhalla, "'One White Man I Like Very Much": Intermarriage and the Cultural Encounter in Southern New Zealand, 1829-1850', Journal of Women's History 20, no. 2 (2008): 34-56, doi.org/10.1353/jowh.0.0013.
} 
hegemonic Pākehā masculinity and, by doing so, guaranteed the dominant position of Pākehā men and the subordination of both Pākehā women and non-Pākehā men and women.

Within the rural landscapes of the Waikato and King Country, gender hegemony intersected with other subjectivities, most notably those of ethnicity or race, to justify why certain bodies, modes of living and ways of seeing the world were privileged over others. As other scholars observe, Western ontological constructions of race and property played significant roles in the establishment and maintenance of racial and economic subordination by Indigenous peoples. The 'settled expectations' of Pākehā privilege (as with other forms of White privilege noted in other settler societies) were founded on connections between race/ethnicity, resource rights and the dispossession of Māori from their lands. The quality of being Pākehā itself was a type of 'status property' (to borrow the words of the African American scholar Cheryl Harris) that was reified in law to safeguard unrecognised settler expectations concerning the privileges, advantages, opportunities and power link to the quality of being Pākehā. ${ }^{65}$ Accordingly, generations of Pākehā in the region championed the dispossession of Māori from their lands (through various pieces of legislation as well as the operations of the Native Land Court system) on the basis that Màori (specifically Māori men) failed to 'develop' their lands, and indeed were incapable of being 'good' farmers. In this way, the rural landscapes (comprising thousands of predominately Pākehā-owned farms) of the Waikato and King Country were thoroughly enmeshed in patriarchal settler colonial racial capitalism. ${ }^{66}$

\section{Conclusion}

In this article, we examined the gendered behaviours and norms of Pākehā women and men living in the Waikato and King Country from the 1860s to the 1930s. The deliberate consideration of how gender norms shaped the way people perceived and engaged with their environments opens up a completely new area of inquiry. As we evince, in addition to oral histories, public and private collections hold largely unexplored texts written by different genders about their life on farms, in the bush, in and on the water, and in the sky that offer different perspectives. Significantly, our research offers new insights into how gender norms intersected with class (alongside race) to provide the scaffolding of hegemonic masculinity and femininity in the rural creation and maintenance of the Pākehā landscapes

65 Cheryl I. Harris, 'Whiteness as Property', Harvard Law Review 106, no. 8 (1993): 1709, doi.org/10.2307/ 1341787.

66 Racial capitalism theorising argues that there is multitude of ways in which racism can be employed by economic processes. Two of the most widely recognised manifestations of racial capitalism are labour and land. Laura Pulido, 'Geographies of Race and Ethnicity II: Environmental Racism, Racial Capitalism and State-Sanctioned Violence’, Progress in Human Geography 41, no. 4 (August 2017): 524-33, doi.org/10.1177/0309132516646495. 
of the rural Waikato and King Country. Our examination of Pākehā living in the 'backblocks' of the Waikato and King Country in the late nineteenth and early twentieth centuries demonstrates how particular configurations of gender practice varied across class lines and were infused with racial thinking that positioned Pākehā at the apex of social, racial, economic and gendered orders. Pākehā women affirmed and defended a version of femininity (which was influenced by British gender norms) and depicted non-hegemonic femininities (including Māori and Pākehā working-class women, Māori, and other non-Pākehā) as inferior, uncivilised and socially unacceptable. The Pākehā and Māori women who undertook farm work, as we outlined in this article, were often labelled by others (both Pākehā men and women) as being unfeminine, undesirable, undomestic and irresponsible with their bodies. Women who, by financial necessity or personal preference, engaged in supposedly manly activities (such as animal husbandry, fencing, logging and shearing) were criticised for being in breach of their duties as wives and mothers (women's primary responsibility being the care of their families and husbands). The use of social censure assisted in the maintenance of the gender hegemony, as did specific legal and socioeconomic arrangements, which provided mutually reinforcing narratives that justified the privileging of masculinity over femininity, as well as systems of class and racial inequity. In the King Country and Waikato, hegemonic masculinity and capitalism exalted practices that marginalised Pākehā women's voices and financial independence, which paralleled to some extent the exclusion and oppression of Māori (yet at the same time Pākehā women benefited from Māori dispossession, as did Pākehā men). Yet our study is small-scale, and further research is critically needed to explore this important area of study. In particular, it is vital to consider the ways in which different constructions of masculinities and femininities operated over temporal and spatial scales (as part of systems of gender, class and racial inequities) and influenced how people conceptualised and responded to environmental conditions and changes.

Table 1: List of oral histories examined for this paper

\begin{tabular}{|l|l|l|l|l|l|l|}
\hline & Interviewee & Interviewer & Date & Collection & Archive & Format \\
\hline 1 & $\begin{array}{l}\text { Catherine } \\
\text { Hay }\end{array}$ & $\begin{array}{l}\text { Rachel } \\
\text { McAlpine } \\
1 \text { October } \\
1991\end{array}$ & $\begin{array}{l}\text { Romance } \\
\text { Writers Book } \\
\text { Project }\end{array}$ & $\begin{array}{l}\text { Alexander Turnbull } \\
\text { Library, Wellington } \\
\text { OHA-4414 }\end{array}$ & Cassette \\
\hline 3 & $\begin{array}{l}\text { lan } \\
\text { Henderson } \\
\text { Ethel Reid } \\
\text { Featherson }\end{array}$ & Terry Harpe & 26 April 2002 & $\begin{array}{l}\text { Agricultural } \\
\text { Heritage } \\
\text { History Project }\end{array}$ & $\begin{array}{l}\text { Alexander Turnbull } \\
\text { Library, Wellington } \\
\text { OHINT-O369-2 }\end{array}$ & Cassette \\
\hline 4 & $\begin{array}{l}\text { Flo (Florence) } \\
\text { McGovern }\end{array}$ & Jeff Downs & $\begin{array}{l}\text { 18 February } \\
1986\end{array}$ & $\begin{array}{l}\text { Hamilton } \\
\text { Libraries Oral } \\
\text { Histories } \\
\text { Collections }\end{array}$ & $\begin{array}{l}\text { Hamilton } \\
\text { Libraries Oral } \\
\text { Libries OH1009 } \\
\text { Histories } \\
\text { Collections }\end{array}$ & Cassette \\
\hline Libraries OH0039 & Cassette \\
\hline
\end{tabular}




\begin{tabular}{|c|c|c|c|c|c|c|}
\hline & Interviewee & Interviewer & Date & Collection & Archive & Format \\
\hline 5 & Mary Meyer & Vicki Jones & 1996 & $\begin{array}{l}\text { Hamilton } \\
\text { Libraries } \\
\text { Oral History } \\
\text { Collections } \\
\end{array}$ & $\begin{array}{l}\text { Hamilton City } \\
\text { Libraries } \mathrm{OH} 1018\end{array}$ & Cassette \\
\hline 6 & $\begin{array}{l}\text { Frederick } \\
\text { Louis } \\
\text { Johansson }\end{array}$ & $\begin{array}{l}\text { Pam } \\
\text { Johansson }\end{array}$ & 1973 & $\begin{array}{l}\text { Hamilton } \\
\text { Libraries } \\
\text { Oral History } \\
\text { Collections }\end{array}$ & $\begin{array}{l}\text { Hamilton City } \\
\text { Libraries OHO334 }\end{array}$ & Cassette \\
\hline 7 & $\begin{array}{l}\text { Frances } \\
\text { Higgins }\end{array}$ & Vicki Jones & 1991 & $\begin{array}{l}\text { Hamilton } \\
\text { Libraries } \\
\text { Oral History } \\
\text { Collections }\end{array}$ & $\begin{array}{l}\text { Hamilton City } \\
\text { Libraries OH0148 }\end{array}$ & Cassette \\
\hline 8 & Sam Taylor & $\begin{array}{l}\text { Julie Stace } \\
\text { Brooke- } \\
\text { White }\end{array}$ & $\begin{array}{l}30 \text { August } \\
2007\end{array}$ & $\begin{array}{l}\text { Molesworth } \\
\text { Oral History } \\
\text { Project }\end{array}$ & $\begin{array}{l}\text { Alexander Turnbull } \\
\text { Library, Wellington } \\
\text { OHINT-0868-05 }\end{array}$ & Cassette \\
\hline 9 & $\begin{array}{l}\text { Ethel May } \\
\text { Booth }\end{array}$ & $\begin{array}{l}\text { Margaret } \\
\text { Voyle }\end{array}$ & 1986 & $\begin{array}{l}\text { Hamilton } \\
\text { Libraries } \\
\text { Oral History } \\
\text { Collections }\end{array}$ & $\begin{array}{l}\text { Hamilton City } \\
\text { Libraries OH0036 }\end{array}$ & Cassette \\
\hline 10 & $\begin{array}{l}\text { Roland Eric } \\
\text { Ward }\end{array}$ & $\begin{array}{l}\text { Jacqui } \\
\text { Remnant }\end{array}$ & 2004 & $\begin{array}{l}\text { Hamilton } \\
\text { Libraries } \\
\text { Oral History } \\
\text { Collections } \\
\end{array}$ & $\begin{array}{l}\text { Hamilton City } \\
\text { Libraries OH0403 }\end{array}$ & Cassette \\
\hline 11 & $\begin{array}{l}\text { Ngaire } \\
\text { McKain }\end{array}$ & $\begin{array}{l}\text { Loius } \\
\text { McKain }\end{array}$ & $\begin{array}{l}7-29 \text { May } \\
1996\end{array}$ & $\begin{array}{l}\text { Ngahinepouri } \\
\text { Oral History } \\
\text { Project }\end{array}$ & $\begin{array}{l}\text { Hamilton City } \\
\text { Libraries OH1010 }\end{array}$ & Cassette \\
\hline 12 & $\begin{array}{l}\text { Tom and } \\
\text { Myrtle McDell }\end{array}$ & Vicki Jones & $\begin{array}{l}17 \text { December } \\
1991\end{array}$ & $\begin{array}{l}\text { Hamilton } \\
\text { Libraries } \\
\text { Oral History } \\
\text { Collections }\end{array}$ & $\begin{array}{l}\text { Hamilton City } \\
\text { Libraries OHC- } \\
\text { 004503-004504 }\end{array}$ & Cassette \\
\hline 13 & Carol Ivanhoe & Terry Harpe & 19 April 2002 & $\begin{array}{l}\text { Agricultural } \\
\text { Oral History } \\
\text { Project }\end{array}$ & $\begin{array}{l}\text { Alexander Turnbull } \\
\text { Library, Wellington } \\
\text { OHA-3841-5 }\end{array}$ & Cassette \\
\hline 14 & $\begin{array}{l}\text { Samuel } \\
\text { Bruce } \\
\text { Henderson }\end{array}$ & Vicki Jones & $\begin{array}{l}\text { 8-22 July } \\
1996\end{array}$ & $\begin{array}{l}\text { Ngahinepouri } \\
\text { Oral History } \\
\text { Project }\end{array}$ & $\begin{array}{l}\text { Alexander Turnbull } \\
\text { Library, Wellington } \\
\text { OHCOLL-0635/09 }\end{array}$ & Cassette \\
\hline 15 & $\begin{array}{l}\text { Barbara } \\
\text { Gilmore }\end{array}$ & Vicki Jones & 21 May 1996 & $\begin{array}{l}\text { Hamilton } \\
\text { Libraries } \\
\text { Oral History } \\
\text { Collections } \\
\end{array}$ & $\begin{array}{l}\text { Hamilton City } \\
\text { Libraries OH1015 }\end{array}$ & Cassette \\
\hline 16 & $\begin{array}{l}\text { Arthur and } \\
\text { Patricia } \\
\text { Cowan }\end{array}$ & $\begin{array}{l}\text { Shona } \\
\text { McCahon }\end{array}$ & 30 June 2007 & $\begin{array}{l}\text { QEIl National } \\
\text { Trust-Its first } \\
30 \text { years Oral } \\
\text { History Project }\end{array}$ & $\begin{array}{l}\text { Alexander Turnbull } \\
\text { Library, Wellington } \\
\text { OHColl-0864 }\end{array}$ & Cassette \\
\hline 17 & Brian Quinn & $\begin{array}{l}\text { Jacqueline } \\
\text { Foley }\end{array}$ & 24 May 1998 & $\begin{array}{l}\text { Past } \\
\text { Champions } \\
\text { Oral History } \\
\text { Project-The } \\
\text { Golden Shears } \\
\text { History Open } \\
\text { Champions }\end{array}$ & $\begin{array}{l}\text { Alexander Turnbull } \\
\text { Library, Wellington } \\
\text { OHColl-059/13 }\end{array}$ & Cassette \\
\hline
\end{tabular}

Source: The authors. 
This text is taken from International Review of Environmental History, Volume 7 , Issue 1, 2021, edited by James Beattie, Ruth Morgan and Margaret Cook, published 2021 by ANU Press, The Australian National University, Canberra, Australia.

doi.org/10.22459/IREH.07.01.2021.03 